\title{
Moderating Role of Logistics Information Technology on the Logistics Relationships and Logistics Service Quality
}

\author{
Hasnida Zakaria \\ School of Management, University Sains Malaysia, \\ 11800 Penang, Malaysia \\ Email: hasnida@yahoo.com \\ Suhaiza Zailani* \\ Graduate School of Business, University Sains Malaysia, \\ 11800 Penang, Malaysia \\ Email:shmz@usm.my \\ Yudi Fernando \\ School of Management, University Sains Malaysia, \\ 11800 Penang, Malaysia \\ Email: yudhitjoa@gmail.com
}

\begin{abstract}
An amount of research has shown that the adoption of technological innovations is the most important tool for enterprises to keep their competitive advantage. Recently, a body of evidence shows that logistics companies can increase their performance by employing new technologies. Many logistics companies began to improve their operation efficiency by continuous implementation of information or automation technologies according to their business characteristics. Logistics companies should employed new information technologies to raise their service capability in the e-commerce age. The main purpose of this study was to examine the impact of logistics relationships on logistics service quality with logistics information technology as moderator. A total of 109 feedbacks received from the 250 questionnaires distributed. Analysis was done to determine the most significant domain influencing logistics service quality. Results revealed that trust, commitment, communication and satisfactions influence the service quality except for bonding which showed no influence on the logistics service quality. The logistics information technology had no moderate effects on the relationship between logistics relationships and logistics service quality; however, the existence of trust and communication has made the moderation effect viable. The present study makes contribution to the logistics practitioners in practicing harmonized business strategy and suggestion for future studies. This study explore the relationships marketing in developing new construct for relationships dimension, which to explain the significant influence to the logistics industry and also to look for empirical evidence, on the relationships constructs, and contribution to the logistics industry.
\end{abstract}

Keywords: : logistics information technology, logistics relationships, logistics service quality, Malaysia

\section{Introduction}

In a matter of few decades, Malaysia has transformed its economy from agriculture based to a trade-driven

\footnotetext{
*Corresponding Author
}

one. Central to powering the growth of this economic transformation is its trading with other nations. International trade has become a critical component 
of Malaysia's economic engine. Given the importance of international trade to Malaysia, much of which is seaborne, logistics has assumed a very prominent role in providing the backbone to facilitate it. In the field of logistics numerous works have been published (Sohail \& Sohal, 2003) resulting in a host of definitions for the concept of logistics (Masson-Franzil, 2003) and the outsourcing phenomenon (Tage, 2000). In these articles (Colin \& Pache, 1988; Halley, 1999; Pache, 1994; Samii, 2000), logistics is presented as a combination of physical and informational flows. The study thus define logistics as the management and control of physical and informational flows, either by internal means or by outsourced means along a chain from the input to the output encompassing all the operations of transport, stock, manufacturing, and packaging, distribution and so on carried out for the customer's satisfaction and in optimized performance conditions for the company. Logistics has evolved through several stages. Seen as a supportive function in the 1960s, it slowly became a strategic function in the mid-1980s (Jones \& Riley, 1985) with the emergence of the concept of Supply Chain Management (SCM), among others. SCM is a fashionable logistic strategy. Stock and Lambert (2001) define it as a component of eight businesses: customers' relationship management, customer service management, demand management, order fulfillment, manufacturing flow management, procurement, product development/commercialization and returns.

Transport sector covers maritime, aviation and land modes in which, sea and air transport services are the two main exportable components of the transport sector in Malaysia. Logistics has assumed a very prominent role as it provides the back bone to facilitate international trade. Logistics value chain involves integration of various service providers - transport, distribution, freight and ancillary services to deliver a total supply chain solution. To give more focus on this sub-sector, the Government has set up the Malaysia Logistics Council (MLC) in February 2007 to be the focal point for the overall coordination on strategies, policies, regulations and rules for the logistics sector (MPC, 2008). Logistics has emerged from merely a supporting activity that facilitates trade to a crucial sector by which the nation's competitiveness is measured. Such is its strategic value today that businesses and foreign investors make decisions to enter into a country based on the adequacy and efficiency of its logistics industry. Part of the success of Malaysia as one of the 20 top trading nations in the world is its ability to offer comprehensive, reliable and cost competitive logistics services to manufacturers and shippers.

By understanding the importance of service quality to the logistics industry, it is essential to examine the factors influencing the service quality. Previous researchers indicated, relationships are a new way to improve quality of services. Rahman (2004) revealed that good relationships are one way of customer retention and foundation to improve company revenue. In addition to this, Payanides and So (2005) in Hong Kong revealed that relationships between logistics users and provider in Hong Kong has influenced the level of services delivered to the customer. Same result produced in Fynes et al., (2004) which study on the relationships and supply chain performance, revealed by having good relationships has transformed the company becoming more innovative. Instead of focusing on the relationships logistics, this study will emphasize on the logistics information technology in influencing the quality service. Quality is a subjective measure which can be translated in many ways by different users; it is ongoing problems embedded along with the logistics process which will influence the performance of the company. According to Yong (2002) generally there is a supportive environment to the global logistics in Malaysia. Zakarian and Zailani (2009) supported the statement given by Yong (2002). This study, however, provides an attractive argument by pointing out that even when the supportive environment is provided, the logistics service quality could still impact firms' logistics management. Given this situation, the logistics service quality is an interesting issue to study. This study aims to explore on the role of logistics technology system as a moderator on the relationship between logistics relationships with logistics service quality. The following section describes the importance of logistics, relationships and hypothesis. This is followed by the methodology and analysis. The paper ends with the conclusions.

\section{Literature Review}

\subsection{The Importance of Relationships in Logistics}

As logistics business is grooming, there is a need for collaboration between the parties for a better business 
relationships. As was mentioned by Dr Michael Hammer "collaboration allows companies to leverage each other on an operational basis so that together they can perform better than separately". Relationship is the condition where a supplier is working towards creating value to their customers (Peter \& Davis, 2008). This condition will only arise when both parties have continuous cooperation in creating the bonding between each other to satisfy each other's needs. Relationships will benefit both parties which encourage them to share information and resources for the benefit of the parties' involved (Chen et al., 2008). A relationship was built based on the commitment, time and efforts. Moreover, both partners must have the same value and understandings (Zineldin, 2004). A study by Batt and Rexha (2000) revealed that a positive relationship between supplier and buyer will enhance quality services. This is supported by Carmamero (2007) who mentioned that relationships between customer and seller are greater foundation for service quality, as close relationships with key suppliers will improve the quality of services delivered at reduced costs (Vijay \& Keah, 2006). Relationships is crucial for all businesses, particularly for the business which involve high level of commitment and integrity, as high relationships is the determinant factor for successful of the company (Cheng et al., 2008). Strong relationships between customer and supplier will reduce uncertainties in the service provided; this will increase customer confidence towards the supplier capabilities and will benefit suppliers in the long run. This will increase retention rate and automatically will eliminate them from shifting to competitors.

\subsection{Relationships Dimensions}

There are few dimensions of relationships model constructed in the previous studies. Based on the commitment trust theory developed by (Morgan \& Hunt 1994), trust and commitment are independents antecedent to relationships outcome and failing to include in the independent will result to less variance explained with the outcome. According to Jungbok et al., (2003), trust, satisfaction and commitment used to investigate the difference in culture between importer and exporter relationships. Results showed that all three dimensions are relatively important. In Payanides and So (2005), trust, bonding, communication, shared value, and empathy were used to study the performance of third part logistics provider; and all dimensions indicated importance in influencing the relationships, trust scored the most which was indicated by the highest beta. In Yau et al., (2000), the dimension of trust, bonding, empathy and reciprocity was used to measure the construction if relationships marketing. This study will investigate the dimensions of trust, satisfaction, bonding, communication, and commitment, which are mostly used in the construction of relationships dimensions.

\subsection{Logistics Service Quality}

Logistics Service quality has been conceptualized as process (Mentzer et al., 2001) the movement of goods, from point of ordering to point of destination. This process is valued by customers, and it is not only to achieve competitive advantage by achieving costs competitive but also improving marketing effectiveness. Logistics service quality is a physical and operational logistics process which is in line with marketing. This process is considered as a result from the unique and complex characteristics of logistics which is not quantifiable, separable and heterogeneous (Parasuraman et al 1985). In Mentzer and Speh, (1995) revealed, firm can create and achieve competitive advantage through excellence in logistic service. Further study was done in Mentzer and William, (2001) whom also supported the earlier study, which revealed that in order to excel in logistics, operation department must have a good coordination and collaboration with marketing department.

Logistics concept has changed overtime as changes in the logistics landscape in term of value creation and services offered. However, this change is still in the operational based concept. According to Lalonde and Zinzer in Mentzer et al, (2001) there are three components make up logistics services. They are satisfying customers needs, measurement of customer satisfaction and commitment to the services. Logistics service quality was measured based on the value created by the provider to the logistics customers. It is due to quality of logistics service is one of the marketing dimension in satisfying customer needs and wants. The traditional way of describing successful logistics service is, on time delivery whereby the goods arrived at the destination at the right time, in the good and right conditions and right price (Mentzer et al., 2001). 


\subsection{Logistics Information Technology}

One of the most critical components of effective logistics services is adequate information technology systems support (Prahalad \& Krishnan, 1999). Information technology can have significant effects on logistics operations, facilitating collaboration among supply chain partners, as well as allowing the automation of many routine logistics activities, thus enabling logistics professionals to focus on more strategic issues in logistics management (Benjamin \& Wigand, 1995; Handfield \& Nichols, 1999). Indeed, from the advent of Electronic Data Interchange, through more modern iterations of supplier/customer networking such as Wal-Mart's Collaborative Forecasting and Replenishment (CFAR) process or vendor-managed inventory processes, information technology is the common thread. To consider how to improve the quality of logistics services without considering the impact of information technology would be to omit from the theoretical framework one of the most important tools for controlling consistency and improving efficiency that modern business has at its disposal.

Study by Razzque (2007), revealed the development of business and technology in third world countries is in the infancy state. He further added that one of the reason why third world country unable to cope with the current business changes was due to lack of information and communication technology (ICT) development. Information technology was one of the factors contributed to the successful of Dell and Wall Mart, which through ICT have made them known as a leader in logistics and supply chain (Srivasta, 2006). According to Closs et al., (1997), information technology has influenced the overall logistics operations capabilities in terms of productivity and service quality, through on time and accurate information with a minimum costs. In addition, study by Lalonde and Master (1994) revealed that logistics process can be meaningful and successful with the usage of ICT. This will help company achieving competitive advantage in term of costs effective; as a result from reduce cycle time and increase productivity and reliability (Sauvage, 2003).

Through logistics information technology, companies can increase competitiveness and sustain competitive advantage. As mentioned in logistics handbook "logistics applications control, primary value-added activities necessary for firm stability and profitability means for integration and flexibility". According to Hammant (1995), investment in the information technology is good for future business. It brings greater benefits to the logistics companies in future as system enables management to monitor inventory at all locations throughout the organization and help the companies in facilitating the intercompany integration. Based on a study by Irene et al., (2008) there are six major areas that information technology can help supply chain and logistics in achieving competitive strategy. These areas are planning and coordination between customers and suppliers, virtual enterprise, online business and ecommerce, infrastructure, management, and implementation. However, there is also a limitation to fully integrate the information technology in business as the companies must be prepared in terms of financial and legal aspects. Closs and Savitske (2003) mentioned that the usage of information technology in logistics companies will help companies achieve internal integration and performance but this approach will not be successful for external operations as companies are more equipped to implement and upgrading internal systems rather than outside. Usage of information technology is one way in improving quality of services and costs reduction, which leads to reliability and efficiency of data transfer (Paroonjpitikul, 1998).

\subsection{Development of Framework}

Figure 1 shows the theoretical framework. The aim is to examine the relative importance of logistics relationships, which consists of five domains, namely trust, commitment, communication, satisfaction and bonding as independent variables to the extensive use of logistics information technology as the moderator.

\section{Methodology}

\subsection{Research Design}

The population of this research is logistics companies' in Penang, Malaysia. Specifically, the population of this study is active logistics companies which are registered with Royal Malaysia custom Pulau Pinang (active logistics company is those who representing more than two customers, which is still operating and dealing with custom related matters). Sampling is a process of selecting a sufficient number of elements from the population by selecting the right sample. The 
Figure 1. Theoretical Framework

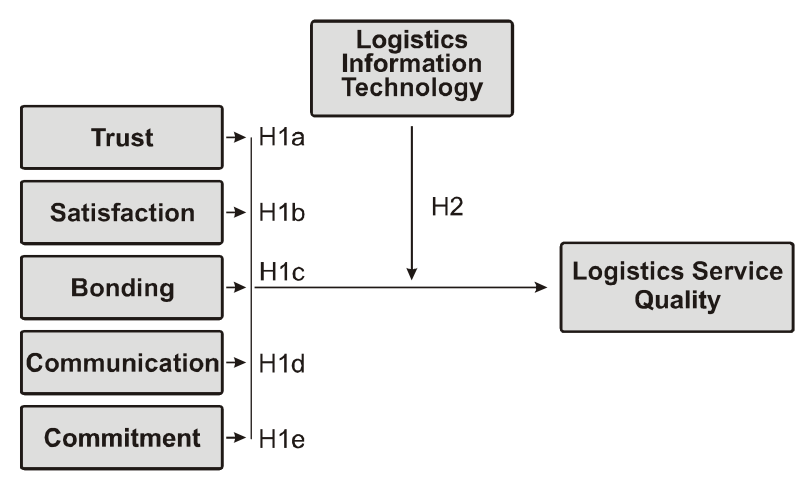

sampling technique used for this research is based on convenience sampling. According to Sekaran (2003), "convenience sampling refers to collection of information from the member of population who are conveniently available to adopt it". These 200 companies were selected based on criteria that complete information with address and contact number of person in charge. This is in line with Sekaran (2003) which states a sample size of 30 to 500 is sufficient for most research. In addition, Roscoe's rule of thumb suggest samples sizes that are greater than 30 and less than 500 should be appropriate for most research. The minimum sample should be at least 10 times than the number of variables. However, larger sample size is preferable as the response rate obtained from an email survey is generally very low (Faria \& Dickinson, 1996). Unit of analysis is based on the company instead of individual. This believed successful implementation of logistics relationships will be effective if it has been implemented in company level.

\subsection{Data Collection Method}

The data collection was conducted in two stages. At the initial stage, questionnaires were sent to all logistics companies operating in Penang and Butterworth using drop off method. The researcher personally went to the said logistics companies and met the respondents face to face. The respondents who could not complete the questionnaires on time were given two weeks to complete and return the questionnaires either by hand or by mail using the self address envelops stamped. On the same time, the questionnaires were sent through email for those logistics companies which are not accessible or not welcoming for drop-off method. Second stage, researcher personally went and distribute the questionnaires at the North Butterwoth container terminal and Bayan Lepas International Airport, where most of the operations personnel performing their job. Regular telephone calls were made as a reminder to the respondents. The questionnaire consists of multiple-choice questions. The response format was based on a positively worded question on 5-point Likert Scale ranging from (1) Strongly Disagree to (5) strongly Agree (Sekaran, 2003). The questionnaire is divided into five sections. Part A is questions on personal information for demographics survey. Part B is on the company profile and Part C on the five independent variables, Part $\mathrm{D}$ is on the dependent variables, which are made up of five items. Last part of the questionnaire is on the moderating variable.

\section{Analysis}

\subsection{Sample and Profiles}

The questionnaires is prepared and distributed via email and hardcopy to the logistics companies operating in Bayan Lepas, Butterworth and Seberang Jaya. Two hundred questionnaires were randomly distributed to all active logistics companies in Penang and only 109 returned. This gives $54.5 \%$ of return rate. A further $45.5 \%$ refused to participate. The reasons for the refusal include time constraints and not specified as company policy.

\subsection{Factor Analysis}

Kaiser-Meyer-Olkin (KMO) measure of sampling adequacy was used to determine the availability of sufficient number of significant correlations between items for factor analysis, to which its significance was tested with Bartlett's test of Sphericity. The factor analysis was conducted for independent variable of logistics relationship which consisted of 5 dimensions in each variable namely: (trust, bonding, communication, commitment and satisfaction). Logistics relationship comprises of five dimensions with 16 items in total. All 16 items were subjected to varimax rotated principal components factor analysis. When extracting with criterion of eigenvalue-greaterthan-one, five factors solution which explained $78.50 \%$ 
of variance was derived. The retention decision of each item was based on factor loadings were greater than or equal to 0.50 and cross-loading with the other factors generally smaller than 0.35 (Igbaria et al., 1995).

Table 1 show that the Kaiser Meyer-Olkin measure of sampling adequacy was 0.72 . High values (close to 1.0) generally indicated that a factor analysis may be useful with data. If the value is less than 0.50, the results of the factor analysis probably would not be very useful. The Bartlett's test of sphericity (ChiSquare $=1.088, \mathrm{df}=120, \mathrm{p}<.01$ ) was found to be significant. Bartlett's test of sphericity indicates whether correlation matrix is an identity matrix, which would indicate that variables are unrelated. The chi-Square significant level was less than 0.01. Therefore, a value higher than about 0.10 or so may indicate that data are not suitable for factor analysis. The diagonal entries of the anti-image correlation matrix range form 0.60 to 0.83 . All of the anti-image values were greater than 0.50 , indicating sufficient correlations among the items. The communalities for a given variable in Table 1 can be interpreted as the proportion of variation in that variable explained by the five factors. The communalities were treated to assess the model of logistic relationship through factor analysis. Most communalities values are close to one and values are arranged from 0.61 and 0.90 . All the values are over 0.50 , which indicates that five factors in logistic relationship explain most of the variation for those 16 items.

The purpose of this factor analysis is to reduce the dimensionality of a large number of items in question into a fewer number of factor. Further factor analysis performed on the moderator variables of the information technology as well as dependent variables of logistic service quality. Factor analysis was run on 7 items, measuring the dimension of the moderating variables. As shown in Table 2 below, the KMO was 0.81 (Chi square $=844.681, \mathrm{p}<0.01$ ) where the antiimage correlation metric for 7 items were all more than 0.50 . They ranged from 0.77 to 0.94 , which demonstrated sufficient correlations among the items and demonstrated measures of sampling adequacy. The Bartlett's test of sphericity was significant at 0.01 levels. One factor was performed and accounted for $74.60 \%$ of the variance explained. The Eigen value is

Table 1. Factor analysis for logistic relationship

\begin{tabular}{|c|c|c|c|c|c|c|}
\hline \multirow{2}{*}{ Relationships between logistics operators and their clients } & \multicolumn{5}{|c|}{ Factor } & \multirow{2}{*}{ Communalities } \\
\hline & 1 & 2 & 3 & 4 & 5 & \\
\hline $\begin{array}{l}\text { Trust } \\
\text { Our clients are trustworthy } \\
\text { We trust each other in all situations } \\
\text { When making important decision they consider our welfare as their own }\end{array}$ & $\begin{array}{r}.935 \\
.919 \\
.873 \\
\end{array}$ & $\begin{array}{r}.092 \\
.096 \\
.064\end{array}$ & $\begin{array}{l}.072 \\
.089 \\
.073\end{array}$ & $\begin{array}{r}.128 \\
.140 \\
-.056\end{array}$ & $\begin{array}{r}.058 \\
.044 \\
.094\end{array}$ & $\begin{array}{l}.884 \\
.783 \\
.907\end{array}$ \\
\hline $\begin{array}{l}\text { Commitment } \\
\text { The relationships the we have is something we care about } \\
\text { The relationships that we have is very important to us } \\
\text { We are committed to the relationships with our clients } \\
\text { We think that the relationships that we have is much like family }\end{array}$ & $\begin{array}{r}.132 \\
.219 \\
.163 \\
-.164\end{array}$ & $\begin{array}{l}.831 \\
.815 \\
.779 \\
.711 \\
\end{array}$ & $\begin{array}{r}-.102 \\
-.096 \\
.143 \\
.153\end{array}$ & $\begin{array}{r}.099 \\
.309 \\
.208 \\
-.013\end{array}$ & $\begin{array}{r}-.065 \\
.056 \\
.291 \\
.229\end{array}$ & $\begin{array}{l}.852 \\
.838 \\
.839 \\
.792\end{array}$ \\
\hline $\begin{array}{l}\text { Bonding } \\
\text { We both try very hard to establish a long term relationships } \\
\text { We work in close co operations with our clients } \\
\text { We keep in touch constantly with our clients }\end{array}$ & $\begin{array}{l}.017 \\
.088 \\
.128\end{array}$ & $\begin{array}{r}-.069 \\
.094 \\
.032\end{array}$ & $\begin{array}{r}.919 \\
.905 \\
.889 \\
\end{array}$ & $\begin{array}{r}.046 \\
-.053 \\
.167\end{array}$ & $\begin{array}{l}.006 \\
.001 \\
.062\end{array}$ & $\begin{array}{l}.620 \\
.768 \\
.782\end{array}$ \\
\hline $\begin{array}{l}\text { Satisfaction } \\
\text { We are satisfied with our clients performance in doing business } \\
\text { In general our relationships with our clients are satisfactory } \\
\text { Our clients has been fair to us }\end{array}$ & $\begin{array}{l}.055 \\
.148 \\
.000\end{array}$ & $\begin{array}{l}.169 \\
.228 \\
.058\end{array}$ & $\begin{array}{r}-.058 \\
.018 \\
.238\end{array}$ & $\begin{array}{r}.894 \\
.812 \\
.781 \\
\end{array}$ & $\begin{array}{l}.152 \\
.121 \\
.240\end{array}$ & $\begin{array}{l}.820 \\
.608 \\
.732\end{array}$ \\
\hline $\begin{array}{l}\text { Communicate } \\
\text { We communicate and express our opinion to each other frequently } \\
\text { We communicate honestly with our clients } \\
\text { We can show our discontent towards each other through communication }\end{array}$ & $\begin{array}{r}-.044 \\
.227 \\
.048\end{array}$ & $\begin{array}{l}.040 \\
.140 \\
.170\end{array}$ & $\begin{array}{r}-.073 \\
-.050 \\
.180\end{array}$ & $\begin{array}{l}.189 \\
.189 \\
.101\end{array}$ & $\begin{array}{r}.864 \\
.812 \\
.739 \\
\end{array}$ & $\begin{array}{l}.749 \\
.856 \\
.728\end{array}$ \\
\hline Eigen value & 4.715 & 2.601 & 2.196 & 1.678 & 1.369 & \\
\hline Percentage Variance (78.50 \%) & 16.905 & 16.484 & 16.478 & 14.813 & 13.812 & \\
\hline
\end{tabular}


5.222. It is variance in a set of variables explained by a factor of logistic information technology.

Factor analysis was also performed on the dependent variable of logistic service quality. The results in Table 3 below, revealed that KMO is 0.83 and Barlett's Test of Sphericity shows significant level (Chi square $=305.197, \mathrm{p}<0.01$ ). The degree of freedom logistic service quality is 10 . The anti-image correlation metric was greater than $0.50(0.80-0.90)$. There was one factor extracted and the total variance explaining this factor was $69.21 \%$ with Eigen value equal to 3.461 . The communalities values represented the proportion of variable's variance explained by a factor structure in logistic service quality. The communalities values were obtained from 0.57 to 0.76 .

\subsection{Reliability Analysis}

The reliability analysis was used to construct reliable measurement scale on all variables. Table 4 shows the results of the reliability test. The current study is strived to improve existing reliability of scales already used. The assessments of scale reliability for all variables were based on the correlations between the individual items. The range between 0 and 1 for Cronbach Alpha coefficients showed the reliability of the data. A Cronbach Alpha coefficient is acceptable, if it is higher than 0.5. However, if the Cronbach Alpha is less than 0.5 , it is not acceptable. The values obtained for all the eight variables were above 0.8 which is considered very reliable. Logistic information system scored the highest reliability of 0.94 , while, communication in logistic relationship was the lowest reliability value of 0.79 .

Table 2. Factor analysis for Logistics Information Technology (LIT) Logistics Information Technolog

\begin{tabular}{|l|c|c|}
\hline \multirow{2}{*}{} & \multicolumn{2}{|c|}{ Logistics Information Technology } \\
\cline { 2 - 3 } & Loading & Communalities \\
\hline Warehouse Management & .937 & .783 \\
system & .906 & .821 \\
Freight Consolidation & .885 & .626 \\
Electronic Data Interchange & .859 & .878 \\
( EDI ) & .851 & .725 \\
Bar coding & .806 & .739 \\
Vehicle routing/scheduling & .791 & .649 \\
Radio frequency & \multicolumn{2}{|c|}{5.222} \\
Communication technology & $74.60 \%$ \\
Performance Measures & \multicolumn{2}{|c|}{} \\
\hline Eigen value & \multicolumn{2}{|c|}{} \\
\hline Percentage Variance & & \\
\hline
\end{tabular}

Table 3. Factor analysis for logistic service quality

\begin{tabular}{|c|c|c|}
\hline & \multicolumn{2}{|c|}{ Logistic Service Quality } \\
\hline & Loading & Communalities \\
\hline $\begin{array}{l}\text { We are always willing to help } \\
\text { our clients (2) }\end{array}$ & .872 & .676 \\
\hline $\begin{array}{l}\text { We give individual attention } \\
\text { to our customer (4) }\end{array}$ & .866 & .760 \\
\hline $\begin{array}{l}\text { We have a modern looking } \\
\text { office equipment (5) }\end{array}$ & .839 & .572 \\
\hline $\begin{array}{l}\text { We are knowledgeable } \\
\text { to answer customer query (1) }\end{array}$ & .822 & .750 \\
\hline $\begin{array}{l}\text { We performed service right } \\
\text { the first time (3) }\end{array}$ & .756 & .703 \\
\hline Eigen value & \multicolumn{2}{|c|}{3.461} \\
\hline Percentage Variance & \multicolumn{2}{|c|}{$69.21 \%$} \\
\hline
\end{tabular}

\subsection{Descriptive Analysis for Variables}

The dependent and independent variables were measured based on a 5-Point Likert scale. The mean and standard deviation of all the variables were summarized in Table 5 below. Based on the results below, the centre value distribution for all variables ranged from 3.58 to 4.12 . The highest mean was commitment (4.12) and the lowest mean was bonding (3.58). The majority of respondents showed that the level of agreement for all major dimensions in this study. Standard deviation was used to measure the spread of the distribution about the mean. The highest standard deviation was bonding (1.02) and the lowest mean was logistics information technology (0.67).

Table 6 presents the results of multiple regression analysis for logistic service quality. Thus, to capture the specific picture in logistic service quality, the control variable was employed. The logistics service quality

Table 4. Results of the reliability test

\begin{tabular}{|l|c|c|c|}
\hline \multicolumn{1}{|c|}{ Variable } & No of Item & Item Dropped & $\begin{array}{c}\text { Cronbach's } \\
\text { Alpha }\end{array}$ \\
\hline Trust & 3 & - & .918 \\
Bonding & 3 & - & .903 \\
Communication & 3 & - & .792 \\
Commitment & 4 & - & .831 \\
Satisfaction & 3 & - & .839 \\
Logistic Service Quality & 5 & - & .888 \\
Logistic information & 7 & - & .943 \\
System & & & \\
\hline
\end{tabular}


was normally more effective in the large size organization. Therefore, the large size organization has been identified with the number of employees. The current study has two control variables and employed dummy coded: organizations that have more than 200 employees were defined as large size organization and organizations that operated with joint venture ownership. The current study has controlled the variable on specific type of ownership. Type of organization was joint venture ownership organization with 30 percent local equity included in this study. Referring to Table 6, DLZO refers to dummy variable for large size organization and $\mathrm{DJVb}$ was defined as dummy variable for the organization that has joint venture ownership. This study utilize dummy variable to capture a variety of qualitative effects on categorical variables. Most of the hypotheses stated in the study were categories as categorical variables which different values. Dummy variables are useful because they enable us to use a single regression equation to represent multiple groups (Fernando et al., 2008).

Table 6 shows result of regression analysis for logistic service quality. Model 1 shows the regression analysis with the control variables, that is, large size organization and joint venture ownership organization with 30 percent local equity. The model was significant with $R^{2}=0.06$, adjusted $R^{2}=0.05, R^{2}$ change $=0.06$, and $F$ change $3.791(p<05)$. It was found the control variables contributed to the model. Model 2 displays the findings after the inclusion of the independent variables with the control variables. After statistically controlling average duration of QMS courses was taken, the model improved significantly. The $\mathrm{R}^{2}$ was 0.45 , followed by the adjusted $\mathrm{R}^{2} 0.42, \mathrm{R}^{2}$ change 0.39 and $F$ change 14.400 ( $p<001)$. This model provides evidence of positive and significant

Table 5. Results of the descriptive statistic

\begin{tabular}{|l|c|c|}
\hline & Mean & Std. Deviation \\
\hline Trust & 3.91 & .85 \\
Bonding & 3.58 & 1.02 \\
Communicate & 3.79 & .77 \\
Commitment & 4.12 & .71 \\
Satisfaction & 3.74 & .75 \\
Logistic Service Quality & 3.60 & .99 \\
Logistic information Technology & 3.92 & .67 \\
\hline
\end{tabular}

Table 6. Result of Regression Analysis for logistic service quality

\begin{tabular}{|l|r|r|}
\hline \multicolumn{1}{|c|}{ Variable } & $\begin{array}{r}\text { Std. Beta } \\
\text { Model 1 }\end{array}$ & $\begin{array}{r}\text { Std. Beta } \\
\text { Model 2 }\end{array}$ \\
\hline Control Variable & $-.215^{\star}$ & -.168 \\
DLZ0 & $.249^{*}$ & .041 \\
DJVb & & \\
Predictor Variable & & $.383^{\star \star \star}$ \\
Trust & & -.077 \\
Bonding & & $.228^{\star}$ \\
Communication & & $.195^{\star}$ \\
Commitment & & $.196^{*}$ \\
Satisfaction & $3.791^{*}$ & $12.060^{\star \star *}$ \\
F & .067 & .458 \\
R $^{2}$ & .050 & .420 \\
Adjusted R ${ }^{*}$ & $3.791^{*}$ & $14.400^{\star \star \star}$ \\
F $^{2}$ Change & .067 & .390 \\
R $^{2}$ Change & & \\
\hline
\end{tabular}

Note: ${ }^{*} \mathrm{p}<0.05,{ }^{* \star} \mathrm{p}<0.01,{ }^{\star \star \star} \mathrm{p}<0.001$

relationship between factors that influence logistic service quality. The predictor variables such as trust $(\beta=0.38, p<.001)$, communication $(\beta=0.22, p<.05)$, commitment $(\beta=0.19, p<.05)$, and satisfaction $(\beta=0.19, p<.05)$ were found to be positively and significant correlated with dependent variable. Besides, the bonding did not show the relationship with the dependent variable. In other words, the bonding is not positively correlated with logistic service quality. As a result hypotheses H.1.a, H.1.c, H.1.d and H.1.e were supported and H.1.b was not.

\subsection{Moderating Effect of Logistic Information Technology on the Logistic Service Quality}

Table 7 present the results of the moderator effect of logistic information technology on logistic service quality. Model 1 shows the regression analysis with the control variables, that is, size of organization (DLZO) and type of ownership (DJVb). The model was significant with $\mathrm{R}^{2}=0.06$, adjusted $\mathrm{R}^{2}=0.05, \mathrm{R}^{2}$ change $=0.06$, and F change 3.791 ( $\left.\mathrm{p}<.05\right)$. It was found that the control variables contributed to the model. Joint venture of ownership were found to be positively correlated on dependent variable ( $\beta=0.25, \mathrm{p}<.05)$ and large size of organization has negative relationship with logistic service quality ( $\beta$ $=-0.21, \mathrm{p}>.05$ ). Model 2 displays the findings after including of the independent variables with the 
control variables. After statistically controlling the size and type of organization, the model improved significantly. The $\mathrm{R}^{2}$ was 0.46 , followed by the adjusted $R^{2}=0.42, R^{2}$ change $=0.39$, and $14.400 \mathrm{~F}$ change $14.400(\mathrm{p}<.001)$. This model provides evidence of positive and significant relationship between factors that influences the logistic service quality. The predictor variables such as trust $(\beta=0.38$, $\mathrm{p}<.001)$, communication $(\beta=0.23, \mathrm{p}<.05)$, commitment $(\beta=0.19, \mathrm{p}<.05)$, and satisfaction $(\beta=$ $0.19, \mathrm{p}<.05)$ were found to be positively and significant correlated with dependent variable. Bonding was found not significant correlated with logistic service quality $(\beta=-0.07, \mathrm{p}>.05)$.

Model 3 presents the findings including the moderating variable. This step was to identify whether logistic information technology act as a moderator to factors that influences the logistic service quality. The model was significant with $\mathrm{R}^{2}$ increase to 0.46 , adjusted $R^{2}=0.42, R^{2}$ change $=0.002$, and $F$ change 0.439. Logistic information technology had no moderate effects to relationship between independent

Table 7. Result of Regression Analysis for Cognitive

\begin{tabular}{|c|c|c|c|c|}
\hline Variable & $\begin{array}{l}\text { Std Beta } \\
\text { Model } 1\end{array}$ & $\begin{array}{l}\text { Std Beta } \\
\text { Model } 2\end{array}$ & $\begin{array}{l}\text { Std Beta } \\
\text { Model } 3\end{array}$ & $\begin{array}{l}\text { Std Beta } \\
\text { Model } 4\end{array}$ \\
\hline $\begin{array}{l}\text { Control Variable } \\
\text { DLZO } \\
\text { DJVb }\end{array}$ & $\begin{array}{r}-.215^{\star} \\
.249^{\star}\end{array}$ & $\begin{array}{r}-.168 \\
.041\end{array}$ & $\begin{array}{r}-.166 \\
.038\end{array}$ & $\begin{array}{r}-.160 \\
.007\end{array}$ \\
\hline $\begin{array}{l}\text { Predictor Variable } \\
\text { Trust } \\
\text { Bonding } \\
\text { Communication } \\
\text { Commitment } \\
\text { Satisfaction }\end{array}$ & & $\begin{array}{r}.383^{\star \star \star} \\
-.077 \\
.228^{\star} \\
.195^{\star} \\
.196^{\star}\end{array}$ & $\begin{array}{r}.361^{\star \star \star} \\
-.101 \\
.223^{\star} \\
.202^{\star} \\
.199^{\star}\end{array}$ & $\begin{array}{r}.912^{\star \star \star} \\
.169 \\
-.658 \\
.345 \\
.325\end{array}$ \\
\hline $\begin{array}{l}\text { Moderator Variable } \\
\text { LIT } \\
\text { Interaction } \\
\text { Trust X LIT } \\
\text { Bonding X LIT } \\
\text { Communication X LIT } \\
\text { Commitment X LIT } \\
\text { Satisfaction X LIT } \\
\text { F } \\
\mathrm{R}^{2} \\
\text { Adjusted R2 } \\
\mathrm{F}^{2} \text { Change } \\
\mathrm{R}^{2} \text { Change }\end{array}$ & $\begin{array}{r}3.791^{*} \\
.067 \\
.050 \\
3.791^{*} \\
.067\end{array}$ & $\begin{array}{r}12.060^{\star \star \star} \\
.458 \\
.420 \\
14.400^{\star \star \star} \\
.390\end{array}$ & $\begin{array}{r}10.548^{\star \star \star} \\
.460 \\
.417 \\
.439 \\
.002\end{array}$ & $\begin{array}{r}.326 \\
-1.249^{\star} \\
-.424 \\
1.584^{\star} \\
-.203 \\
-.207 \\
8.243^{\star *} \\
.533 \\
.417 \\
2.919^{\star} \\
.073\end{array}$ \\
\hline
\end{tabular}

Note: ${ }^{*} p<0.05,{ }^{* \star} p<0.01,{ }^{* \star \star} p<0.001$ and dependent variable. This model found trust $(\beta=$ $0.36, \mathrm{p}<.001)$, communication $(\beta=0.22, \mathrm{p}<.05)$, commitment $(\beta=0.20, p<.05)$ and satisfaction $(\beta=$ $0.20, p<.05)$ were significantly correlated with dependent variable. Bonding reveal that does not have relationship with dependent variable $(\beta=-0.10$, $\mathrm{p}>.05$ ). Model 4 shows the result for the moderating effect of logistic service quality on logistic relationship and logistic service quality. This is achieved by including the interaction terms together with the control variables, independent variables, and a moderator. The $\mathrm{R}^{2}$ increase to 0.53 , adjusted $\mathrm{R}^{2}=0.42, \mathrm{R}^{2}$ change $=0.073$, and $\mathrm{F}$ change 2.919 $(p<05)$. The model remained significant and there is interaction between logistic information technologies as moderator on logistic service quality. Overall model 2 was able to explain $45 \%$ of the variance on logistic service quality. Model 3 was able to explain $46 \%$ of the variance on factors that logistic service quality with $42 \%$ attributed to a moderator effect. Finally, model 4 was able to explain $53 \%$ of variance on factors that influence the effectiveness of QMS system in manufacturing organization in Penang with $42 \%$ attributed to the interaction terms.

\subsection{Simple Slope of the Moderating Effect}

Based on figure 2 the graph can interpret the patterns between low and high trust on logistic service quality. Slope is that statistical interactions occur when lines are not parallel. The demarcation of "Low" and "High" for the variables were conducted based on the criteria of \pm 1 standard deviation. The difference of logistic service quality between low and high trust was not parallel. The interaction graph will occurs under condition high of disruption. In other words, the degree of the moderating variable has its greatest impact under this particular value for the main effect of disruption. In particular it had a positive effect under conditions of high disruption. The mean for high trust was proportionally lower than high trust in logistic relationship on logistic service quality.

The plot of the communication and the logistic service quality shows a pattern that is consistent with the prediction variable. In Figure 3, the line represents the relationship between communication and logistic service quality shows a difference slope in different 
level of logistic information technology. It is not surprising that the higher communication in logistic relationship with high level of logistic information technology was rated as highly level of logistic service quality. The lower the communication appears to be, the less influencing the logistic service quality is. Result of the multiple regression done on the logistics service quality, was found that the control variables (large size organization and joint venture ownership organization with $30 \%$ local equity) contributed to the model. It was significantly correlated to the dependent variables. The model shows that, there are positive relationships between predictor variables such as trust, communication, commitment and satisfaction to the dependent variable. However bonding does not show positive relationships with the dependent variable.

For hierarchical regression done on the moderator effect of the logistics information technology on logistics service quality, it was found that the control variables contributed to the model with the existence of control variables (size of the organization and type of ownership). It was also found that joint venture of ownership were positively correlated on the dependent variable. However the size of organization has negative relationships with the logistics service quality. After inclusion of factor variables, model provide significant relationships between predictor variables of trust,

Figure 2. The Interaction Graph between Trust and the Logistic Service Quality

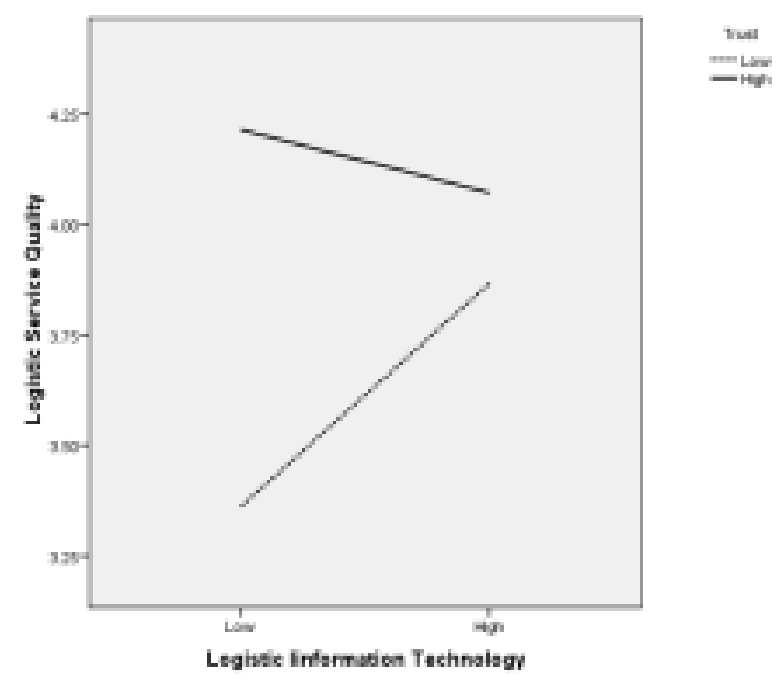

Figure 3. The Interaction Graph between Communication and the Logistic Service Quality

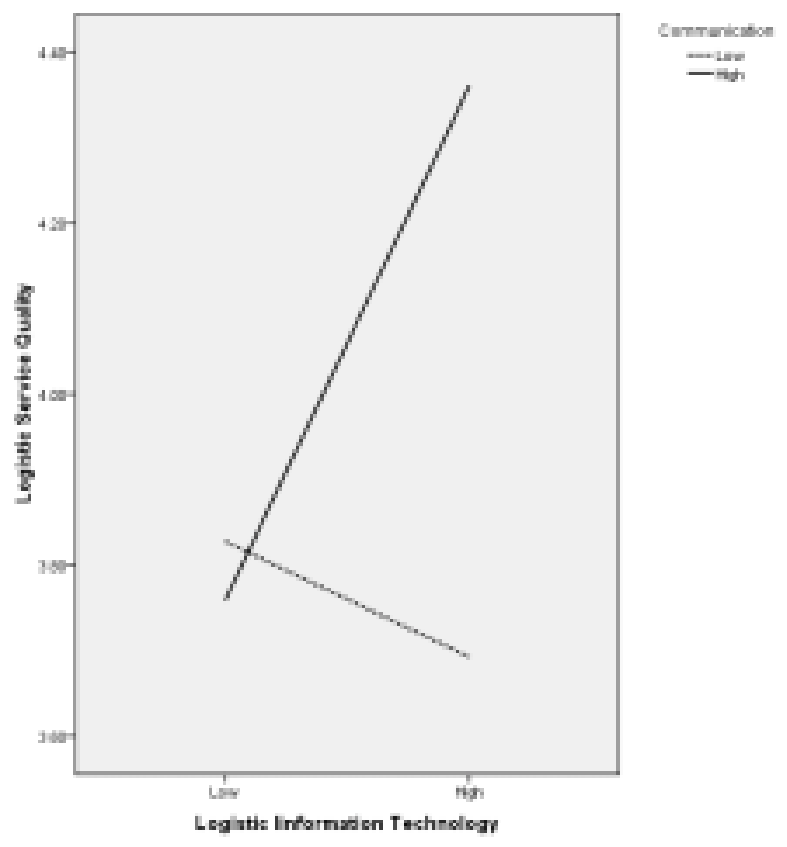

commitment, communication and satisfaction to the logistics service quality but, bonding shows no significant relationships to the logistics service quality. Hierarchical regression analysis done to identify whether logistics information technology act as a moderator to the predictor variables that influence logistics service quality. It was found that there is no moderate effect to the relationships; however independent variables were significantly correlated to the dependent variable except for bonding. Beside that, an interaction between Logistics information technology on logistics service quality also exist in the present of trust and communication. The findings indicate that the dimensions of logistics relationships construct are positively influence the service quality of the logistics company in Penang. This finding support the proposal of logistics relationships can influence the service performance of the logistics company in Penang, in delivering quality of services to customers.

\section{Discussions}

With respect to the different dimensions impact to the logistics service quality, trust was found the most 
important factor influencing service quality provided. The result is consistent with the study by (Payanides \& So, 2005) on the impact of integrated logistics relationships and service quality performance. The study was done in Hong Kong on the relationships between logistics provider and users, shows, trust demonstrated the highest significant level which compared to other dimensions. This is may be due to nature of this business which is risky and costs sensitive, it involved processes and needed more cooperation and coordination between partners who are dealing with operations, planning and delivery of goods. Without trust, they cannot perform the job properly and smoothly. In logistics, the efficient movement and costs effective are their ultimate goals and objectives. Distrust of any partner may jeopardize their business relationships and may incur additional operational costs as a result of improper planning and coordination.

Other dimensions such as commitment, communication, and satisfaction are consistent to previous results that showed all the items are crucial for relationships. Information sharing or communication will lead to a better result (Tian et al, 2008). In logistics service, both partners must have a mutual understanding towards the job they are performing; effective communication and also willingness to share ideas with partners will give a greater impact to the end result. This is important especially in the planning and coordination to perform just in time delivery and error free consignment. The results of multiple regression showed that satisfaction and commitment constantly have the same result and weight. These two items carry the same value to the logistics company in Penang. Satisfied person will perform the job better, this is supported by Martin et al (1998), who highlighted that dissatisfied parties will break the commitment. Commitment and satisfaction are important as logistics is round the clock activity where highly committed personnel are required to perform the job effectively and efficiently regardless of gender and position. They carry a very big responsibility; slightly error may jeopardize the whole business process. Productions may stop with regards to the failure of logistics provider to deliver at the promised time.

It is surprising to know that bonding do not have relationships with service quality. Bonding in chiao, (1982) plays an important role in managing social and business conduct in the society and also acting as an agent in enhancing long term business relationships. Levitt, (1983) this inconsistent finding has to further explored in future study. The moderator in this study is logistics information technology. The results of this study revealed that logistics information technology had no moderate effects to the relationships logistics. This result contrasts with the studies done by Irene $e t$ al., (2008) which showed that Information and communication technology (ICT) improved quality of the service to the customer. This study, showed logistics information technology moderated the relationships in the existence of trust and communication. This may be because most of the logistics companies in Penang do not fully utilize information and ICT in their daily business transactions due to costs constraint and lack of experience personnel in handling the machines, as most of the respondences came from medium-level companies to compared to large organizations studied by Irene et al., (2008). In these companies, the average turnover was 32Million Euro. This is because these companies more emphasize on upgrading internal system rather than external system which indicated low relationships (Closs et al, 1997).

\subsection{Conclusion}

This study has several limitations that can be over come in future research for a better result. The first limitation is the feedback from the people involving in this industry is not much encouraging, as most Chinese respondents as well as Joint Venture Company are reluctant to cooperate with the study. Chinese in the joint venture company are not open for study which compared to Malay and local company. The second limitation is the time constrains as 4 months were given to complete the study, better result could be obtained if more time given. The third limitation is, study was done in the logistics practitioner's side which is not taking into consideration logistics user's point of view. This does not represent the actual logistics world scenario. The sample should cover all the logistics companies in Penang and if possible to work closely with Logistics associations in Penang in order for them to enforce the association members to respond to the questionnaires distributed. Next research should try to get the response from all logistics practitioners, especially for external and joint venture company in 
order to have different management perspective, and culture. Finally, next research should emphasize more on the usage of logistics information technology by segregating the number of respondents based on the size of the company and ownerships as extensive use of information technology are more depending on the size and capital structure of the company. In conclusion to this study is to recognize the role of relationships or Guangxi in the day to day of logistics operations. It revealed that relationships dimensions of trust, commitment, satisfaction and communications need to be endeavor by company marketing personnel or whoever dealings with customers in order to have a good and quality business practices. The usage of information technology in daily business operations in Penang has no significant impact to the service quality provided. Hope this study can contribute to the logistics industry in Penang to equip them with a new knowledge in logistics business.

\section{References}

Batt, P. J., and Rexha, N., (2000), Trust: A Determinant Or The Consequence Of A Long-Term Buyer Seller Relationship? Australian \& New Zealand Marketing Academy Conference, 28.11-1.12.2000.

Benjamin, R. I., and Wigand, R. T. (1995), Electronic markets and virtual value chains on the information highway, Sloan Management Review, 36(2), pp. 62-72.

Camarero, C. (2007), Relationships orientation of service quality? What is the trigger performance in financial and insurance service, The international Journal of bank Marketing, 25(6), pp.406-425.

Chen, A. J. W., Boudreau, M. C., and Watson, R.T. (2008), Information systems and ecological sustainability, Journal of Systems and Information Technology, 10 (3), pp.186-201.

Cheng, X. Z., Shi,Y., and Dong, D. H. (2008), An empirical study of relationship quality in a service setting a Chinese case, Marketing Intelligence \& Planning, 26(1), pp.11-25.

Chiao, C.A. (1982), A modest proposal on 'relationship', in Yang, K.-S., Wen, C.-I. (Eds), Sinicization of Social and Behavioral Science Research in China, Institute of Ethnology Academia Sinica, Taiwan, pp.345-60.

Closs J.D., Goldsby, J.T., and Clincton, R. S. (1997), Information technology influence on world class capability, International Journal of Physical Distribution and Logistics Management, 27(1), pp.4-17.
Closs, D.J., and Savitskie, K. (2003), Internal and external logistics information technology integration, International Journal of Logistics Management, 14 (1), pp.63-76.

Colin, J., and Pache, G. (1988). La logistique de Distribution: l'avenir du marketing. Paris, France: Chotard et Associés.

Faria, A. J., and Dickinson, J. R. (1996), The effect of reassured anonymity and sponsor on mail survey response rate and speed with a business population, Journal of Business $\mathcal{E}$ Industrial Marketing, 11(1), pp.6676.

Fernando, Y., Janbi, L., and Zailani, S. (2008), The Worker Characteristic And Determinant Factors Of Safety Compliance At Processing Area, The International Conference On Social Sciences And Humanities, $18^{\text {th }}$ $20^{\text {th }}$ June 2008, Penang, Malaysia.

Fynes, B., de Bu'rca, S., and Voss, C. (2004), Supply chain relationship quality, the competitive environment and performance, International Journal of Production Research, 43(16), pp. 3303-20.

Hammant, J. (1995), Information Technology Trends in Logistics, Logistics Information Management, 8(6), pp. 32-37.

Handfield, R. B., and Nichols, E. L. Jr. (1999), Introduction to Supply Chain Management, Prentice-Hall, Upper Saddle River, NJ

Igbaria, M., Guimaraes, T., and Davis, G.B. (1995), Testing the determinants of microcomputer usage via a structural equation model, Journal of Management Information Systems, 11(4), pp.87-114.

Saura, I. G., Francés, D.S., Contrí, G.B., and Blasco, M.F. (2008), Logistics service quality: a new way to loyalty, Industrial Management \& Data Systems, 108(5), pp.650 - 668 .

Jones, T., and Riley, D.W. (1985), Using inventory for competitive advantage through supply chain management, International Journal of Physical Distribution and Materials Management, 15(5), pp.1626.

Jungbok, H., Kiran, K., and Anusorn, S. (2004), Importer's relationships with exporters: does Culture matter?, International Marketing Review, 21(45), pp.417-46.

Lalonde, B.J., and Master, J.M. (1994), Emerging logistics strategies blueprint for next century, International Journal of Physical Distribution and Logistics Management, 24(7), pp. 35-47.

LaLonde, B.J., and Zinzer, P.H. (1976), Customer Service: Meaning and Measurement, National Council of Physical Distribution Management, Chicago, IL.

Levitt, T. (1983), After the sale is over, Harvard Business Review, 61(5), pp.87-93. 
Martin, M. (1998), Trust leadership, Journal of Leadership Studies, 5, pp.41-50.

Masson-Franzil, Y. (2003), La logistique revisitée, In Actes des communications à la deuxième Journée d'Etudes AOSI, University of Metz, France, pp. 67-93.

Mentzer, J. T., and William, L. R. (2001), the role of logistics leverage in Marketing strategy, Journal of Marketing Channel, 8(3/4), pp.29-48.

Mentzer, J. T., and Kenneth, B. K. (1995), A Framework of Logistics Research, Journal of Business Logistics, 16(1), pp. 231-250.

Mentzer, T.J., Flint, J.D., and Hult, H.T.G. (2001), Logistics service quality as a segment-customized process: Journal of Marketing, 65, pp. 82-104.

Morgan, R.E., and Hunt, S.D. (1994), The commitmenttrust theory of relationship marketing, Journal of Marketing, 58, pp.20-38.

Pache, G. (1994), La logistique: enjeux stratégiques, Paris, France: Vuibert

Parasuraman, A.V., Zeithaml, A., and Berry, L. A. (1985), A conceptual model of service quality and implication for future Research, Journal of Marketing, 49, pp 41-50.

Payanides, P. M., and So, M. (2005), The Impact Of Integrated Logistics Relationships On Third-Party Logistics Service Quality and Performance, Maritime Economics and Logistics, 7, pp. 36- 35.

Davis, P.R. (2008), A relationship approach to construction supply chains, Industrial Management $\mathcal{E}$ Data Systems, 108(3), pp.310-327.

Prahalad, C. K., and Krishnan, M.S. (1999), The new meaning of quality in the information age, Harvard Business Review, pp.109-18.

Rahman, Z. (2004), Developing customer orientated service, a case study, Managing service Quality, 14 (5), pp.426-435.

Razzaque A, M. (2007), Challenges to logistics development; the case of $3^{\text {rd }}$ world country-Bangladesh, Journal of Physical Distribution $\mathcal{E}$ Logistics Management, 27(1), pp.18-38.

Samii, A. K. (2000), Stratégies Logistiques Fondements Méthodes, Applications. Paris, France: Dunod.
Sauvage, T. (2003), The relationship between technology and logistics $3^{\text {rd }}$ party provider, International Journal of Physical Distribution and Logistics Management, 33(3), pp.236-253.

Sekaran, U. (2003), Research Methods for Business - A Skill Building Approach. Fourth Edition, John Wiley \& Sons, Inc.

Sohail, M. A., and Sohal, A. S. (2003), The used of third party logistics service in Malaysia Perspective, Technovation, 23, pp. 401-408.

Srivasta. S.K. (2006), Vision 2000, The Journal of Process Perspective, 10(3).

Stock, J.R., and Lambert D. M. (2001), Strategic Logistics Management, McGraw-Hill International, 4th edition, New York.

Tage, S. L. (2000), Third Party Logistics-From an interorganizational point of view, International Journal of Physical Distribution \& Logistics Management, 30(2).

Tian, Y., Lai, F., and Daniel, F. (2008), An examination of the nature of trust in logistics outsourcing relationship: empirical evidence from China, Industrial Management $\mathcal{E}$ Data Systems, 108(3), pp.346-67.

Vijay, R. K., and Keah, C. T. (2006), Buyer supplier Relationships: The impact of supplier selection and buyer-supplier engagement on relationships and firm performance International Journal of Physical Distribution $\mathcal{E}$ Logistics Management, 36(10).

Yau, O. H. M., Mcfetridge, P.R., Chow, R. P. M., Lee, J. S. Y., Sin, L.Y.M., and Tse, A.C.B. (2000), Is relationship marketing for everyone? European Journal of Marketing, 34(9/10), pp.1111-1127.

Yong, N. L. (2002), MITI, data accessed on 18/09/08, data retrieved at www.miti.gov.my

Zakaria, H., and Zailani, S. (2009), An Empirical Study on the Logistics Service Quality: The Role of Logistics Relationship, International Journal of Logistics and Transport, 3(2).

Zineldin, M. (2004), Co-opetition: the organization of the future, Marketing Intelligence \& Planning, 22 (7), pp.780-789.

Hasnida Zakaria was an MBA student in the School of Management, Universiti Sains Malaysia. Her primary researches of interests are in the areas of operation management and strategy focusing on supply chain related activities.

Suhaiza Zailani, Ph.D. is an Associate Professor of Operations Management in the Graduate School of Business, Universiti Sains Malaysia. She received her Ph.D and MSc. from the Lancaster University and Bsc. Degree from the Universiti Pertanian Malaysia. Dr Suhaiza's primary research interests are in the areas of operations and production management, product and service quality management and productivity. She 
has published in International Journal of Benchmarking, International Journal of Operations and Production Management, OR Insight, International Journal of Information Management, Sasin Journal of Management, and Asian Academy of Management Journal.

Yudi Fernando is a PhD candidate at the School of Management, USM. His research area is in the supply chain. 